\title{
A brief study on environmental protection management in P.R.C.
}

\author{
B. B. Zhang, D. He, H. Chua \& Y. F. Tsang \\ Department of Civil and Structural Engineering, \\ the Hong Kong Polytechnic University, China
}

\begin{abstract}
Environmental pollution has become one of the hottest topics in recent years throughout the world including the mainland of China. Along with economic growth, pollutants have increased year by year in the People's Republic of China (P.R.C.). Although the Chinese government does make efforts to treat pollutants and tries their best to prevent further environmental degradation, criticisms of the highly polluted environment come from both domestic and overseas sources on the government's administrative methods and implementations. We choose parameters such as GDP per capita, waste emissions and investment to illustrate the current situation of environmental protection investment and the Chinese economic level. Therefore, an analysis can be conducted to assess the investment and also the policy implementation on the basis of a special developing period. We find that the invested area has some differences between P.R.C. and other western countries because of the degree of pollution. Additionally, the legislations that were made under the Chinese central-controlled law system cannot be effectively enforced since there is a lack of supervision mechanism such as that of western countries. Finally, political suggestions will be given.
\end{abstract}

Keywords: environmental protection, PRC, management, legislation.

\section{Introduction}

An enviable economic performance has been achieved over the last two decades in China. While the increasing GDP per capita has brought a wealthy life to the people in China, vast quantities of natural resources have been consumed and a worsening living environment has been created $[1,2,7]$. 
In order to provide a technical guarantee, at least 400 nationwide special criterions have been set down, including Ecological Quality Standard, Discharge Standard, Pollution Controlled Basic Standard, Environmental Protection Method Standard... All of them are a component of the environmental protection system.

According to the Environmental Annual Report 2004 (EAR [16]), the country's environmental quality stood at a stable level and slightly improved during past decades while the GDP increased to maintain a high percentage. Ground water and main rivers maintain a good quality of water while rivers in northern China were highly polluted; drinking water in most big cities reached the national standards; ocean water except Dong and Bo oceans progressed a little; although air quality was significantly improved, part of the heavyindustrial cities were heavily polluted; and noise quality was controlled to high standards.

However, this "stable level" cannot satisfy citizens and the whole world. When other countries make great efforts to protect their atmosphere, China becomes the origin of pollution, which pulls down the worlds' environmental protection and pollution treatment progress.

\section{Methodology}

\subsection{Materials}

The website of the National Bureau of Statistics of China, Chinese statistics yearbook (annually, 1973-2005) published by China Statistic Press, China environmental yearbook (annually, 1999-2005) published by China Environmental Science Press, the website of State Environmental Protection Administration of China, the website of the US Environmental Protection Agency, the website of World Bank, and many other investigation reports are useful data sources for this study.

One problem that must be tackled is that data from the above sources is not exactly the same. When there are discrepancies among data, two classes of data have two ways to settle. (I) For data related to China, data from the website of the National Bureau of Statistics of China has the priority since this study aims at assessing the environmental protection investment in PRC and the National Bureau of Statistics of China has the authority to publish renewed statistical data. The second selected sources are the China statistic yearbook, the China environment yearbook and the website of the State Environmental Protection Administration. (II) With regard to the other class of data, for data related to western countries, each country's EPA website will firstly be referred to. Data in publications are always corrected with updated information each year and this is considered to be an authentic source worldwide, thus data from the website of the World Bank and other investigation reports helped to make a choice when selecting data and acted as a supplement to official published data.

After data collection, we first investigate the performance of the Chinese economy in order to understand the general situation in China. After that, we 
begin to detect the relationship between China's industry and its economy. We try to find out whether Chinese industry takes the same percentage in its GDP as other developed countries. Meanwhile, we highlight China's economic reforms which led to China's economy boost and that depend more upon industry than agriculture. In this part, we emphasis the State-owned-enterprises' role in environmental protection. Environmental research and Chinese laws and regulations on the environment are introduced thereafter to prepare for being compared with developed countries. We also find out the investment in treating pollution by the Chinese government to show the investment trend. Finally, a specific legislation comparison is conducted and many suggestions were given to the Chinese government.

\section{Polluting factors and legislation}

\subsection{China's economy}

After the mid-1990s, the when the economy was insufficient, the real increase rate of the economy was mostly determined by demand. At the same time, China has had a fabulous economic gain during recent decades. Table 1 shows the GDP growth rate, industrial production, and some data on environmental protection from 1995-2004 (STATS [3]).

Table 1: $\quad$ China economic situation 1995-2004.

\begin{tabular}{|l|l|l|l|l|l|l|l|l|l|l|}
\hline Year & 1995 & 1996 & 1997 & 1998 & 1999 & 2000 & 2001 & 2002 & 2003 & 2004 \\
\hline $\begin{array}{l}\text { (1) GDP (10 } \\
\text { million million } \\
\text { yuan) }\end{array}$ & 5.85 & 6.79 & 7.45 & 7.83 & 8.21 & 8.95 & 9.73 & 10.52 & 11.74 & 13.69 \\
\hline $\begin{array}{l}\text { (2) Investment } \\
\text { in the treatment } \\
\text { of } \\
\text { environmental } \\
\text { pollution (1 } \\
\text { billion Yuan) }\end{array}$ & ---- & ---- & ---- & ---- & ---- & 101.5 & 110.7 & 136.7 & 162.8 & 191.0 \\
\hline $\begin{array}{l}\text { (1)/ (2) (\%) } \\
\text { Direct Economic } \\
\text { Loss Due to } \\
\text { Pollution (1 } \\
\text { billion Yuan })\end{array}$ & ----- & ----- & ---- & ---- & ---- & 1.13 & 1.14 & 1.30 & 1.39 & 1.40 \\
\hline $\begin{array}{l}\text { Industrial } \\
\text { production (1 } \\
\text { million million } \\
\text { yuan) }\end{array}$ & 2.47 & 2.91 & 3.24 & 3.34 & 3.51 & 3.91 & 4.24 & 4.60 & 5.31 & 6.28 \\
\hline $\begin{array}{l}\text { Total Population } \\
\text { (1 billion } \\
\text { persons) }\end{array}$ & 1.21 & 1.22 & 1.24 & 1.25 & 1.26 & 1.27 & 1.28 & 1.28 & 1.29 & 1.30 \\
\hline
\end{tabular}


From table 1, we can find that the increased rate of investment in the treatment of environmental pollution is growing faster than that of GDP in China. However, the former is still a tiny proportion of the latter. It is prospected that in 2020, the population in China will reach 1.4 billion to 1.5 billion, and the GDP will again increase (Cao. et al [4]). In addition, large populations that have a strong consumer ability need a great deal of goods. So, there must be a continual and fast economic rise in the following 5 to 15 years.

Accordingly, China consumed $31 \%$ of the world's coal, $30 \%$ of the ironstone, $27 \%$ of the rolled steels and $40 \%$ of the cement in 2003 , while creating no more than $4 \%$ of the global GDP. Simultaneously, compared with developed countries, the waste water discharge in China is 5 times per unit GDP higher and solid pollution produced by the Unit Gross Industrial Output Value is 10 times more than developed countries. Last year, the discharge of $\mathrm{SO}_{2}$ was the highest in the world. These amazing data shows the highly increased economy pays for the fearful environmental degradation and the increased rate of the gross industrial output value is mainly due to heavy industry, which is maintained year after year. Therefore, if we do nothing with the environment, the pollution will increase four to five times, which cannot be afforded by the environment.

\subsection{Relationship between China's industry and economy}

The employment rate is one of the indicators in evaluating a country's economic performance. The primary industry is defined as agriculture (including farming, forestry, animal husbandry and fishery). The secondary industry is defined as industry (including mining and quarrying, manufacturing, production and supply of electricity, water and gas) and construction. Tertiary industry refers to all other industries not included in the primary or secondary industries (STATS [3]). Table 2 shows the employment by type of industry in different countries.

Table 2: $\quad$ Employment by type of industry (\%).

\begin{tabular}{|l|l|l|l|l|l|l|}
\hline \multirow{2}{*}{ Country } & \multicolumn{2}{|l|}{ Primary industry } & \multicolumn{3}{l|}{ Secondary industry } & \multicolumn{2}{l|}{$\begin{array}{l}\text { Tertiary } \\
\text { industry }\end{array}$} \\
\cline { 2 - 7 } & 2000 & 2001 & 2000 & 2001 & 2000 & 2001 \\
\hline China & & 50.0 & 22.5 & 22.3 & 27.5 & 27.7 \\
\hline United Kingdom & 1.5 & 1.4 & 25.4 & 24.9 & 72.7 & 73.4 \\
\hline Unites States & 2.6 & 2.4 & 22.9 & 22.4 & 74.5 & 75.2 \\
\hline Germany & 2.7 & 2.6 & 33.4 & 32.5 & 63.8 & 64.7 \\
\hline
\end{tabular}

Compared with the developed countries, the primary industry plays a much greater part in the industrial structure. This factor must be considered in making environmental policy. Since this kind of framework not only brings in environmental pollution, but also limits the economic development.

From the other point of view, the rates of nondurable industry's production effect GDP, which directly shows the economic dependence on industry.

The different economic reliance on high polluting industry can be clearly found and the hardest point in treating the Chinese environmental problem can 
be revealed, which is the economy is led by nondurable industry. Tables 3 and 4 $[3,5]$ also reveal the conflict between economic growth and environmental protection in China.

\subsection{Effect of China's economic reforms}

China's industrial output has been growing at an average annual rate of over 11.4 percent since the start of economic reforms in 1978 (STATS [3]). This unprecedented pace and scale of industrial growth has not only greatly improved

Table 3: Relationship between nondurable industry and economy in China $(\%)$.

\begin{tabular}{|l|l|l|l|l|l|l|}
\hline Industry & 1999 & 2000 & 2001 & 2002 & 2003 & 2004 \\
\hline Paper making & 2.2 & 2.3 & 2.3 & 2.2 & 2.4 & 2.2 \\
\hline Food and Beverage & 11.6 & 11.3 & 10.3 & 10.2 & 10.1 & 9.1 \\
\hline Chemical & 9.1 & 9.6 & 9.2 & 7.8 & 9.5 & 8.3 \\
\hline Textile & 6.6 & 6.1 & 5.6 & 5.0 & 4.8 & 4.4 \\
\hline Total & 29.5 & 29.3 & 27.4 & 25.2 & 26.8 & 23.9 \\
\hline
\end{tabular}

Table 4: $\quad$ Relationship between nondurable industry and economy in the US.

\begin{tabular}{|l|l|l|l|l|l|l|l|}
\hline \multirow{2}{*}{ Industry } & \multicolumn{6}{|l|}{ Current dollars (billions of dollars) } \\
\cline { 2 - 9 } & 1998 & 1999 & 2000 & 2001 & 2002 & 2003 & 2004 \\
\hline GDP & $8,747.0$ & $9,268.4$ & $9,817.0$ & $10,128.0$ & $10,469.6$ & $10,971.3$ & $11,734.3$ \\
\hline Nondurable goods & 537.0 & 552.7 & 561.0 & 562.5 & 577.9 & 583.7 & 596.1 \\
\hline $\begin{array}{l}\text { Food and } \\
\text { beverage and } \\
\text { tobacco products }\end{array}$ & 137.5 & 153.6 & 154.8 & 167.1 & 172.9 & 170.6 & 167.9 \\
\hline $\begin{array}{l}\text { Textile mills and } \\
\text { textile product } \\
\text { mills }\end{array}$ & 27.1 & 26.4 & 26.5 & 22.7 & 21.9 & 22.7 & 23.3 \\
\hline $\begin{array}{l}\text { Apparel and } \\
\text { leather and allied } \\
\text { products }\end{array}$ & 26.0 & 24.7 & 25.1 & 22.8 & 20.9 & 18.4 & 18.9 \\
\hline Paper products & 52.2 & 54.2 & 55.6 & 48.9 & 50.3 & 46.4 & 48.9 \\
\hline $\begin{array}{l}\text { Printing and } \\
\text { related support } \\
\text { activities }\end{array}$ & 46.5 & 48.2 & 49.0 & 46.9 & 45.7 & 44.5 & 45.9 \\
\hline $\begin{array}{l}\text { Petroleum and } \\
\text { coal products }\end{array}$ & 30.6 & 22.4 & 26.2 & 33.4 & 26.2 & 33.5 & 34.8 \\
\hline $\begin{array}{l}\text { Chemical } \\
\text { products }\end{array}$ & 153.4 & 157.1 & 157.1 & 157.2 & 174.4 & 181.8 & 186.0 \\
\hline $\begin{array}{l}\text { Plastics and } \\
\text { rubber products }\end{array}$ & 63.6 & 66.1 & 66.7 & 63.4 & 65.5 & 65.6 & 70.3 \\
\hline $\begin{array}{l}\text { Percentage that } \\
\text { Industrial } \\
\text { production take in } \\
\text { GDP (\%) }\end{array}$ & 6.1 & 5.9 & 5.7 & 5.5 & 5.5 & 5.3 & 5.1 \\
\hline
\end{tabular}


the quality of life of 1.3 billion Chinese, but also caused significant environmental risks for public and ecological health at local, regional, and global levels (World Bank [1]).

Despite China's increasingly vigorous efforts in curbing industrial pollution over the last two decades, industry remains the principal culprit of environmental deterioration in China. For example, industry accounted for 83 percent of total sulphur dioxide $\left(\mathrm{SO}_{2}\right)$ emissions and over 80 percent of total particulate emissions in 2003. (STATS [3])

Industrial energy consumption accounted for more than 68 percent of the total energy consumption in China from 1990 to 2002, and industry consumed 90 per cent of total coal consumption in China (STATS [3]). China was the largest consumer of coal, the second largest consumer of oil and the second largest emitter of the greenhouse gas carbon dioxide in 2002. (IEA [6])

China began to develop a system of environmental institutions, regulations and programmes in the wake of growing pollution in the 1970s (Smil [7]; Ma and Ortolano [8]). These relatively comprehensive environmental controls were in place during the period of rapid industrializations in the 1980s and 1990s, but did not prevent the overall deterioration of environmental quality in China (World Bank [1]).

The National Environmental Protection Agency (NEPA [9]) mandate from 1996 onwards required all industrial enterprises to comply with pollutant discharge standards by the end of 2000, but this achieved limited results. In 2003 about 1.3 million businesses paid pollution levies, most of which were industrial enterprises violating the national pollution discharge standards (NEPA [9]).

A World Bank research report said that the State-Owned Enterprises (SOEs) in China are more intensively polluted than the heavy industries in the US and Europe. This results from the use of old technology, techniques and equipment, which in turn decrease the efficiency of operations. Once the SOEs are facing a lack of profit, they are discouraged from operating in an efficient way. Therefore, it is not difficult to imagine that they are not concerned with the environmental issue under the condition that they are not making profit.

\subsection{Chinese environmental research}

Much environmental research began after 2000. A primary established institution system belonging to the States Environmental Protection Administration of China did much environmental research. For instance, since its establishment, the PRCEE (Research Center for Eco-Environment Sciences) has completed about 100 research projects.

The Department of Water Environment, Chinese Research Academy of Environmental Sciences, and other institutions also take charge of special parts of the environmental protection and prevention research.

\subsection{China's laws and regulations on the environment}

A distinguishing feature of environmental policy-making is the potential for conflict between the many competing interests involved. This is primarily 
because environmental issues span across a huge variety of governmental activities - transport, agriculture, trade and so on - and these separate policy arenas tend to provide a great deal of influence for development-oriented interests.

Being the largest developing country, along with the economic prosperity in the mainland of China during the last 20 years, environmental problems have attracted more attention from the government. The government has mentioned a grandiose target that constructs an overall affluent society by the year 2020 (Cao. et al [10]), in the meantime making a favorable environment an important content of this goal. Sustainable development, raised at the 1992 Rio Earth Summit, was adopted as the main thrust of the Chinese government.

A decision about enhanced environmental protection issued on Feb.3rd, 2005, by the State Department, points to strengthening the environment technical basis construction platform, and the momentous research program of the environment has the priority in the list of the state technology plans.

The government published the greatest number of laws and legislations in 2005. There were 104 environmental protection standards published in 2005, including 26 national pollution emission control standards, 24 national environmental samples, 53 national environmental protection standards and one national pollution prevention technique policy (CEY [11]).

The environmental legislation in China primarily intends to protect the environment while accelerating the speed of economy and society development. It is endeavored to promote and secure the harmonious and uniform advancement between environment protection and economic development.

\subsection{Investment in treating pollution by government}

The government was forced to spend more and more funds treating pollution, since the waste was mainly produced from industry.

Table 5: Investment completed in the treatment of industrial pollution (billion yuan).

\begin{tabular}{|l|l|l|l|l|}
\hline & $\begin{array}{l}\text { Investment } \\
\text { completed in } \\
\text { the treatment } \\
\text { of industrial } \\
\text { pollution this } \\
\text { year }\end{array}$ & $\begin{array}{l}\text { Treatment of } \\
\text { wastewater }\end{array}$ & $\begin{array}{l}\text { Treatment of } \\
\text { waste gas }\end{array}$ & $\begin{array}{l}\text { Treatment of } \\
\text { solid waste }\end{array}$ \\
\hline 2000 & 23.94 & 10.96 & 9.09 & 1.15 \\
\hline 2001 & 17.45 & 7.29 & 6.58 & 1.87 \\
\hline 2002 & 18.83 & 7.15 & 6.98 & 1.61 \\
\hline 2003 & 22.18 & 8.74 & 9.21 & 1.62 \\
\hline 2004 & 30.81 & 10.56 & 14.28 & 2.26 \\
\hline
\end{tabular}




\section{Discussion}

There is much valuable experience and many conclusions in the developed world that should be learned and researched by China. Some differences were found in order to give the Chinese government an example to go through to future work on protecting environment.

\subsection{Similarities and differences in legislations between countries}

\subsubsection{Similarities}

Not only environment law but also corporation law, tax law and many other acts reflect the environmental protection industry, although there are great differences between the law system in China and most western countries especially the investigation mechanism.

There was a revision to the accounting law of Norway (SN [12]) that came into effect from 1999 that required enterprises to describe in their annual reports (or at least in the notes to their annual accounts) about their operations that "do not have inconsiderable influences" on the outside environment (in contrast to the work environment) (Hass and Smith [13]). Similarly, part of Chinese laws, such as the Criminal Law of the People's Republic of China in 1979, the Constitution of the People's Republic of China in 1982 and the Agriculture Law of the People's Republic of China, also refer to environment protection. More than 900 provincial regulations have been established by local government and the local legislature aims at protecting the environment (Zheng and Wang [14]).

\subsubsection{Differences}

4.1.2.1 Education Education on environmental protection consciousness is highlighted here because the success of any environmental policy depends on changing the decision or behaviors of both producers and consumers (Fryxell and Lo [2]).

Most western regions have widely disseminated environmental protection consciousness through government internet (i.e. US environment agency), posters along roads and footbridges (i.e. HKSAR), broadcast, televisions and etc. since the 1970s when OECD countries began to make their environmental laws. After more than three decades, citizens living in developed regions - the consumers - are rejecting products that are not eco-friendly in their daily life. Thus the providers must change their pollution industries into environmentalfriendly patterns to cater to consumers' tastes. Therefore, a good circulation of information is automatically founded without a great mass of governments' interference and this circulation can run smoothly for a very long time.

Germany not only set tightened regulations, but also developed and encouraged the broader application of market-oriented approaches to environmental management. The regulation reforms include information, education, voluntary self-commitments by industries, emission trading, subsidy schemes...

Unfortunately, although the Chinese government put a large amount of capital into the environmental protection industry as mentioned above, they seem to 
have ignored this very important and useful method. The newest environmental plan we can find didn't refer to this point (CEY [15]). Nowadays, people in China can only find environmental quality data, including city air quality daily reports, forecasts of the air quality, weekly outdoor bathing place water quality etc from some of newspapers, magazines and the internet. But no other information such as how to protect surroundings and the significance of choosing green products is widely provided.

4.1.2.2 Investigation mechanism In Germany, the new pattern of policy has been strongly established in the new regulation instruments that are in use, such as risk management and environmental impact assessment. This pattern made all the published policies under investigation and the feedback on the policies can help to review and mend the original ones or supply subsidized legislation.

China's centrally controlled law system is well known by the whole world. Whether this system is good or not, in environmental protection industry this system results in a lack of investigation on legislation. The only way to establish satisfaction of a rule is to wait for government officers to find the ineffectiveness of the rule. The finding period may be at least one year, because the officers need to promulgate the rule into real life and wait for its effect. During this period, although scientists and citizens can give advice, no risk management or environmental impact assessment will be carried out by government.

4.1.2.3 Law-making direction Germany set a good example to states that have a high polluting, industry intensive economy and have largely coal-based power generation, such as China.

Major environmental policy in Germany is different from developing states like China. Their policy is not just a remedy for environmental pollution, but also prevention from new pollution. For instance, the new regulation on the origin of waste water, which targets about 55 industrial and commercial sectors potentially discharging waste water containing dangerous components, defines technical requirements to be met when discharging waste water into rivers and other waters.

In China, although the government highlights the importance of preventing new pollution, pollution levies may be the only direct legislation on preventing it. However, most factories and corporations prefer paying the fine or taxes to reducing their pollution emission because of the expensive costs in technical renewal.

\section{Conclusion}

This paper briefly reviewed the environmental management performance of the Chinese government. After a comparison between China and other countries in pollution management legislation, some management suggestions for China were established. 


\section{Reference}

[1] WORDBANK, www.worldbank.org

[2] Fryxell G.E. and Lo C.W.H., Preferences for dealing with environmental problems: an empirical study of managers in three mainland Chinese cities. Journal of Environmental Management, 64, pp. 35-47, 2002.

[3] STATS, www.stats.gov.cn

[4] Cao D., Yu F., Gao S.T., Zhu B.L., Yan G., Jiang H.Q. and Qi J.M., Economy and Environment: China 2020, China Environmental Science Press: Beijing, pp. 157-160, 2005.

[5] USEPA, www.epa.gov

[6] IEA, www.iea.org

[7] Smil, V., China's environmental crisis: an inquiry into the limits of national development, M.E. Sharpe: N.Y., pp 1-10, 1993.

[8] Ma X.Y and Ortolano, L., Environmental regulation in China: institutions, enforcement, and compliance, Rowman \& Littlefield: Md., pp 1-13, 2000.

[9] NEPA, www.nepa.gov.jm/index.asp

[10] Cao D., Yu F., Gao S.T., Zhu B.L., Yan G., Jiang H.Q. and Qi J.M., Economy and Environment: China 2020, China Environmental Science Press: Beijing, pp. viii - ix, 2005.

[11] China environment yearbook 2005; State Environmental Protection Administration of China. www.sepa.gov.cn/plan/zkgb/05hjgb/

[12] de Caprona, Yann C. and Mona Irene Hansen, Statistics Norway, 1987.

[13] Hass, J.L. and Smith T. Methodology Work for Environmental Protection Investment and Current Expenditures in the Manufacturing Industry Final Report to Eurostat. Statistics Norway, 2002.

[14] Zheng Y.S. and Wang S.W. China environment and development review, Social science documentation publishing house: Beijing, 2001.

[15] China environment yearbook 2005; State Environmental Protection Administration of China. www.sepa.gov.cn/plan/hjgh/sywgh/dsywgh/

[16] Environmental Annual Report 2004; State Environmental Protection Administration of China. http://www.sepa.gov.cn/plan/zkgb/04zkgb/ 